\title{
PROMOTING INTEGRATED WATER RESOURCES MANAGEMENT IN SOUTH WEST NIGERIA: THE NEED FOR COLLABORATION AND PARTNERSHIP
}

\author{
A. Sobowale ${ }^{1^{*}}$, J. K. Adewumi² and O. A. Bamgboye ${ }^{3}$ \\ 1, 2 South West Regional Centre for National Water Resources CAPACity Building Network, \\ FEDERAL UNIVERSITY OF AGRICULTURE, PMB 2240, ABEOKUTA 110001, NIGERIA. \\ 3 NATIONAL WATER RESOURCES INSTITUTE, PMB 2309, KADUNA, NIGERIA. \\ E-mail Addresses:1 sobowalea@funaab.edu.ng,2 jjkadewumi@yahoo.com33sanjobam@yahoo.com
}

\begin{abstract}
This paper elucidates the need to implement Integrated Water Resources Management (IWRM) in South West Nigeria. At present, water related programmes in existing capacity building institutions (CBIs) do not have IWRM and climate change adaptation in their synopsis; this suggests the need for curriculum review. Another observation was that many of the professionals in the water sector organizations (WSOs) are aging with none of these organizations having succession plans. Developing and implementing succession plans require collaboration and partnership with CBIs in the region; the recent establishment of the National Water Resources Capacity Building Network (NWRCBNet) in the country is timely; itwill provide a platform for IWRM implementation and capacity building in the water sector. The south west regional center at the Federal University of Agriculture, Abeokuta has been spear heading this vision and the results achieved so far in the south west region has been encouraging.
\end{abstract}

Keywords: Integrated Water Resources Management, Capacity Building, Water Sector Organizations, Nigeria

\section{INTRODUCTION}

The objective of sustainable water resources development is to make sure that adequate supply of water of good quality and quantity are maintained for the entire population of the world, while preserving the hydrological, biological, and chemical functions of ecosystems, adopting human activities within the capacity limits of nature, combating vectors of water related diseases and adapting to climate change $[1,2]$. In order to achieve the aforementioned, the multidisciplinary nature of water resources development and management must be recognized, as well as the multi interest utilization of water resources for water supply and Sanitation, agriculture, industry and biodiversity etc.

It is widely recognized that an integrated approach to water resource development and management offers the best means of reconciling competing demands with supplies and a framework where effective operational actions can be taken [3]. Integrated Water Resources Management (IWRM) is therefore the way forward if the world's limited freshwater resources must be managed in a sustainable manner $[4,5]$. It is a participatory planning and implementation process, based on scientific knowledge, which brings together stakeholders to determine how to meet society's longterm needs for water and coastal resources while maintaining eco- system and biodiversity. IWRM helps to protect the environment, foster economic growth and sustainable agricultural development, promote democratic participation in governance, and improve human health. Worldwide, water policy and management are beginning to reflect the fundamentally interconnected nature of hydrological resources, and integrated water resources management is emerging as an accepted alternative to the sector-by-sector, top-down management style that has yielded little results in the past. In Nigeria, the concept of IWRM is still at infancy; there is a dearth of knowledge on the need to sustainably develop and manage the nation's water resources. Most of the water resources development project are funded by Government and are interventionist in nature, supplydriven and many of them lack sustainability plans. These are some of the reasons why such projects are short lived; the stakeholders are not carried along in 
the decision process, hence many of the water schemes fail shortly after commissioning. Consider the rural water supply schemes for example, several abandoned borehole dot the landscape of south west Nigeria, these could be seen as one travels along many rural feeder roads; also worth mentioning are the Igbojaiye, Ilero, Ofiki I and II, Sepeteri, Ibarapa/Iseyin, Mokoloki, Asa, Iwo, Okuku, Itoikin, Igbonla, Oogi, Ipetu-Ijesha, Iwopin and Oke-Odan water projects.

The objective of this paper is to elucidate the dire need for IWRM in south west Nigeria and by extension the entire country and the role that capacity building institutions (CBIs) in the region have to play in fast tracking capacity development in the water sector organizations (WSOs) in the region.

\section{THE NEED FOR IWRM CAPACITY BUILDING IN THE WATER SECTOR OF SOUTH WEST NIGERIA}

Since the handing over of governance by the colonial administration in 1960, the water sector in south west Nigeria experienced progress especially through the Western Region Government when a number of rural and peri-urban water schemes were commissioned and functioned effectively for a period of time. But since the intervention of the Military in the polity, the sector began to witness declining investment which led to low capacity utilization of existing water schemes; this subsequently led to the closure of many of the water supply schemes. Attempts were later made to salvage the situation during the second republic 1979 - 1983), but this was also short-lived by instability in governance. The management of these schemes is $100 \%$ controlled by government, hence the frequency of low capacity utilization and lack of sustainable investment in the sector.

One of the problems of the water sector in south west Nigeria is that of low quality personnel especially in the technical aspects. The dearth of key personnel such as Water Engineers, Public Health Engineers or Environmental Engineers and other pertinent professionals in the sector and poor funding has contributed to the very low system performance witnessed all over the south western states of Nigeria. These issues need to be addressed before a pragmatic solution to all the problems can be achieved. It should be noted that the water sector is multi-disciplinary in nature which cuts across professions like Engineering, hydrogeology, hydrology, geography, meteorology, chemistry, finance and accounting, administration, economics, law, sociology, public health, environmental science etc. A major gap in the sector is who should be responsible for what? This is the reason why many reforms implemented in the sector in the past has been short lived. The problem of inappropriate personnel in the water sector has been perpetrated by the concept of on-the-job training; the end result has always been square pegs in round holes. This concept further led to the establishment of training centers by the WSOs in order to make square pegs to become round. Unfortunately, this concept of capacity building has not yielded the much desired efficiency in the sector; hence, the need for a change in strategy.

In the past, capacity building has been viewed to be synonymous with infrastructural development, which is the reason for the massive investment in the water sector at the early stages; however, without the right caliber of personnel to manage the numerous developments, one can only expect system failure or incessant breakdowns of water infrastructures that we now face in the region. Access to water is still very low in the region despite the huge available water resources, the rate of investment in the sector is abysmal when compared with the population growth rate and the rapidly expanding built up areas that we now have in south west Nigeria. The development of the water resources for irrigation in the region is still very low as most of the irrigation schemes developed in the past are grossly underutilized while some have been abandoned.

With the advent of IWRM, the concept of capacity building has changed and the scope expanded. Capacity building is now seen as the process whereby a community equips itself to undertake the necessary functions of governance and service provision in a sustainable manner. The process of capacity building must be aimed at both increasing access to resources and to changing the power relationships between the parties involved. The "community" may be a local government, a village level committee or even a central government department or ministry. Capacity building is not only constrained to officials and technicians but must also include the general awareness of the local population regarding their services and development in general. Greater understanding is needed of the dynamics and processes of capacity building and greater rigor is needed in the planning, design and implementation of capacity building activities. Most "capacity building" initiative in the region is carried out on a project by project basis as a "tack-on" to the main contract of physical service delivery. There is seldom a planning 
process which involves a whole area and which address capacity building and training on a long-term, programmatic basis.

\section{THE PROS AND CONS OF INTEGRATED WATER RESOURCES MANAGEMENT}

Water is important for the sustenance of life; effective management of water resources demands a holistic approach, linking social and economic development with protection of natural ecosystems. Effective management links land and water uses across the whole of a catchment area or groundwater aquifer. The notion that freshwater is a finite resource arises as the hydrological cycle on average yields a fixed quantity of water per time period. This overall quantity cannot yet be altered significantly by human actions, though it can be, and frequently is, depleted by man-made pollution. The freshwater resource is a natural asset that needs to be maintained to ensure that the desired services it provides are sustained. The principle of IWRM recognizes the fact that water is required for many different purposes, functions and services; management therefore, has to be holistic (integrated) and involve consideration of the demands placed on the resource and the threats to it. The integrated approach to management of water resources necessitates co-ordination of the range of human activities which create the demands for water, determine land uses and generate waterborne waste products. This can only be achieved if the catchment area or river basin is seen as the logical unit for water resources management.

Water resources Development in Nigeria has always been seen from the perspective of political boundary rather than the river basin for several decades; this has led to fragmented development of the nation's water resources and has made the management of such development difficult.

Achieving IWRM in south west Nigeria requires the adoption of participatory approach in the development of the region's water resources. This involves raising awareness of the importance of water among policy-makers and the general public. It means that decisions are taken at the lowest appropriate level, with full public consultation and involvement of users in the planning and implementation of water projects.

Real participation will only take place when all stakeholders are part of the decision-making process. The type of participation will depend upon the spatial scale relevant to particular water management and investment decisions. According to [6], participatory approach is the best means for achieving long-lasting consensus and common agreement. Participation is about taking responsibility, recognizing the effect of sectoral actions on other water users and aquatic ecosystems and accepting the need for change to improve the efficiency of water use and allow the sustainable development of the resource. Governments in the region have to help create the opportunity and capacity to participate, particularly among women and other marginalised social groups. It has to be recognized that simply creating participatory opportunities will do nothing for currently disadvantaged groups unless their capacity to participate is enhanced.

The recognition of the fact that women in south west Nigeria play a pivotal role as providers and users of water and guardians of the living environment has seldom been reflected in institutional arrangements for the development and management of water resources. During the recently conducted stakeholder's workshop for the development of Ogun state water supply and sanitation policy (2010), women groups were conspicuously sidetracked in the formulation of the policy. This is very common in Nigeria as a whole. The recognition of the role of women requires positive policies to address women's specific needs and to equip and empower women to participate at all levels in water resources programmes, including decision-making and implementation, in ways defined by them. It is widely acknowledged that women play key roles in the collection and safeguarding of water for domestic use and processing of food crops, but that they have a much less influential role than men in management, problem analysis and the decision-making processes related to water resources. The fact that social and cultural circumstances vary between societies suggests that the need exists to explore different mechanisms for increasing women's access to decision-making and widening the spectrum of activities through which women can participate in water resources management.

IWRM requires gender awareness. In developing the full and effective participation of women at all levels of decision-making, consideration has to be given to the way different societies assign particular social, economic and cultural roles to men and women. There is an important synergy between gender equity and sustainable water management. Involving men and women in influential roles at all levels of water 
management can speed up the achievement of sustainability; and managing water in an integrated and sustainable way contributes significantly to gender equity by improving the access of women and men to water and water-related services to meet their essential needs.

It is vital to recognize that one of the basic human rights is to have access to clean water and sanitation at an affordable price. Thus water has a value as an economic good as well as a social good. Many past failures in water resources management are attributable to the fact that the full value of water has not been recognized and has led to wasteful and environmentally damaging uses of the resource. Treating water as an economic good is an important means for decision making on the allocation of water between different water use sectors and between different uses within a sector. This is particularly important when extending supply is no longer a feasible option.

The value of water in alternative uses is important for the rational allocation of water as a scarce resource, whether by regulatory or economic means. Charging (or not charging) for water is applying an economic instrument to support disadvantaged groups, affect behavior towards conservation and efficient water usage, provide incentives for demand management, ensure cost recovery and signal consumers' willingness to pay for additional investments in water services [7].In IWRM, economic valuation of alternative water uses gives decision makers important guides to investment priorities. It should not though be the only consideration. Social goals are important too. In a water-scarce environment, would it be right, for example, that the next water resource developed should be assigned to a steelmanufacturing plant because the manufacturer can afford to pay more for the water than the thousands of poor people who have no access to safe water? Social, economic and environmental goals all play a part in IWRM decision-making[8].

\section{THE ROLE OF CAPACITY BUILDING INSTITUTIONS (CBIs)}

The poor manpower situation and weaknesses in policy, financial and institutional frameworks within which the agencies in the water sector have to operate in the region has brought to the fore a challenge to the CBIs in the region. The south west of Nigeria is endowed with more number of CBIs than any other geo-political region of Nigeria and hence a vast collection of professionals and scientists who are in a position to brainstorm about the problems and find solutions to the numerous challenges facing the various agencies of Government responsible for water resources development and management (see figure 1).

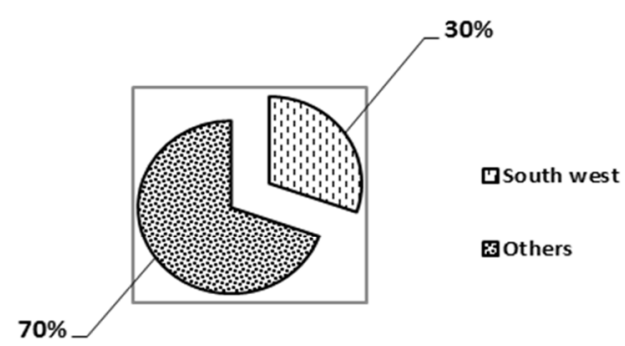

Universities

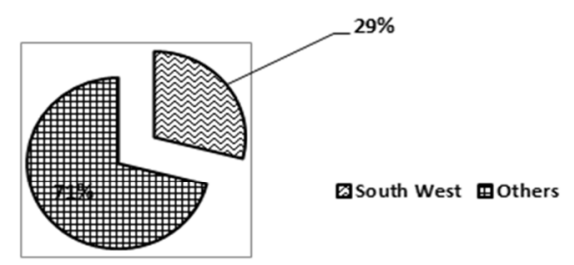

Polytechnics

\section{Figure 1: Percentage of CBIs hosted by South west region of Nigeria}

These CBIs provide the training at the levels specified in water related courses, it should be noted that the courses offered are general in nature. It is essential to also note that this institutions house some of the best professionals in water related disciplines; in order to achieve IWRM in the region, a review of curriculum of many of the courses offered is very necessary in order to streamline some of the programmes to meet the challenges of the water sector in the region. This may not be possible without strength, weakness, opportunities and threat (SWOT) analysis of the respective WSOs in the region; this initial study is needful in order to provide seamless capacity building interventions in the region. It is worthy of note that there is no concrete partnership/linkages between the CBIs and the WSOs in the south west states, this scenario cannot foster the much desired IWRM in the region. The CBIs are in a better position to carryout research into the challenges of water resources development of the region and the operational problems of the WSOs. All these observations point to the need for collaboration in the area of curriculum development for the water related courses the CBIs 
offer, incorporating the principles of IWRM and adaptation to climate change into the course content will make the graduates of these courses to be better poised to address some of the problems of water resources development and management in the region.

\section{HARNESSING THE EXPERTISE OF CBIS THROUGH COLLABORATION: NWRCBNet INITIATIVE}

The most effective way to harness the knowledge base of the CBIs in the region is through collaboration between the CBIs and the WSOs and/or other organs of Government responsible for water. The recent effort of the National Water Resources Institute, Kaduna (NWRI) which is directed towards creating an avenue for collaboration between CBIs and WSOs through the establishment of the National Water Resources Capacity Building Network (NWRCBNet) is a step in the right direction. This network provides an avenue for scientists, Engineers and other professionals in the water sector to tackle problems of the sector and to permit the development and application of IWRM initiatives in the development and management of the water resources of the region. The establishment of the regional (south west) coordinating center of NWRCBNet at the Federal University of Agriculture, Abeokuta is indeed laudable; efforts are now ongoing towards the collation of a database of scientist, Engineers and other professionals in the water sector that are domiciled in the south west of Nigeria. Table 1 shows the distribution of approved CBIs in the region by states and the types of training they provide.

The regional centre is charged with the responsibility of coordinating capacity development in the water sector through education, training, research and information dissemination in the six (6) states of south west Nigeria. The states include Lagos, Ogun, Oyo, Osun, Ekiti and Ondo states. The mission statement is to promote effective partnership for education, training, research and information dissemination on water resources development and management with a view of engendering integrated water resources management and ecosystem sustainability in the south west states of Nigeria. The specific objectives of the network in south west Nigeria includes:

(a) Ensure appropriate and sustainable manpower development for water resources development and management throughout the six south west states.
Table 1: Distribution of approved CBIs in the South

\section{west region}

\begin{tabular}{|c|c|c|}
\hline STATE & CBIs & $\begin{array}{c}\text { Type of } \\
\text { Training }\end{array}$ \\
\hline \multirow{15}{*}{ Ogun } & University of Agriculture, Abeokuta & \multirow{11}{*}{$\begin{array}{c}\text { Bachelor's } \\
\text { Degree }\end{array}$} \\
\hline & Olabisi Onabanjo University, Ago-Iwoye & \\
\hline & Tai Solarin University of Education, & \\
\hline & Ibogun & \\
\hline & Babcock University, Ilisan & \\
\hline & Bells University of Technology, Ota & \\
\hline & Covenant University, Ota & \\
\hline & Crawford University, Igbesa & \\
\hline & Crescent University, Abeokuta & \\
\hline & Redeemer's University, Mowe & \\
\hline & Federal Polytechnic, Ilaro & \\
\hline & Gateway Polytechnic, Sapade & \multirow{4}{*}{ Higher Diploma } \\
\hline & Moshood Abiola Polytechnic, Abeokuta & \\
\hline & Abraham Adesanya Polytecnic, Ijebu-Igbo & \\
\hline & Allover Central Polytecnic, Ota & \\
\hline \multirow{7}{*}{ Oyo } & University of Ibadan, Ibadan & \multirow{5}{*}{$\begin{array}{c}\text { Bachelor's } \\
\text { Degree }\end{array}$} \\
\hline & Ladoke Akintola University of Sci. \& Tech., & \\
\hline & Ogbomoso & \\
\hline & Leadcity University, Ibadan & \\
\hline & Ajayi Crowder University, Oyo & \\
\hline & The Polytechnic, Ibadan & \multirow{2}{*}{ Higher Diploma } \\
\hline & Federal School of Survey, Oyo & \\
\hline \multirow{11}{*}{ Osun } & Obafemi Awolowo University, Ile-Ife & \multirow{6}{*}{$\begin{array}{c}\text { Bachelor's } \\
\text { Degree }\end{array}$} \\
\hline & Bowen University, Iwo & \\
\hline & Osun State University, Oshogbo & \\
\hline & Fountain University, Oshogbo & \\
\hline & Joseph Ayo Babalola University, Ikeji- & \\
\hline & Arakeji & \\
\hline & Federal polytechnic, Ede & \multirow{5}{*}{ Higher Diploma } \\
\hline & Osun State Polytechnic, Iree & \\
\hline & Osun State Coll of Tech, Esa-Oke & \\
\hline & The Polytechnic, Ile-Ife & \\
\hline & Interlink Polytechnic, Ijebu-Ijesa & \\
\hline \multirow{7}{*}{ Ondo } & Federal University of Tech, Akure & \\
\hline & Adekunle Ajasin University, Akungba & \\
\hline & Ondo State University of Sc. \& Tech, & Bachelor's \\
\hline & Okitipupa & Degree \\
\hline & Achiever's University, owo & \\
\hline & Wesley university of Sci. \& Tech, Ondo & \\
\hline & Rufus Giwa Polytechnic, Owo & Higher Diploma \\
\hline \multirow{5}{*}{ Ekiti } & University of Ado-Ekiti, Ado-Ekiti & \multirow{3}{*}{$\begin{array}{c}\text { Bachelor's } \\
\text { Degree }\end{array}$} \\
\hline & The University of Education, Ikere-Ekiti & \\
\hline & Afe Babalola University, Ado-Ekiti & \\
\hline & Federal polytechnic, ado-Ekiti & \multirow{2}{*}{ Higher Diploma } \\
\hline & Crown Polythechnic, Ado-Ekiti & \\
\hline \multirow{9}{*}{ Lagos } & University of Lagos, Akoka & \multirow{3}{*}{$\begin{array}{c}\text { Bachelor's } \\
\text { Degree }\end{array}$} \\
\hline & Lagos State University, Ojo & \\
\hline & Caleb University, Imota & \\
\hline & Yaba College of technology, Yaba & \multirow{6}{*}{ Higher Diploma } \\
\hline & Lago State Polytechnic, Ikorodu & \\
\hline & Grace Polytechnic, Surulere & \\
\hline & Lagos City Polytechnic, Ikeja & \\
\hline & Wolex Polytechnic, Ikeja & \\
\hline & Ronik Polytechnic, Ejigbo & \\
\hline
\end{tabular}

(Source: JAMB Brochure, 2013)

(b) Strengthen Institutions and Human capacity through partnerships for the successful implementation of Integrated Water Resources Management in south west Nigeria. 
(c) Enhance cooperation among Capacity Building Institutions (CBIs) in the region for Integrated Water Resources Management (IWRM).

(d) Facilitate research and demand driven training and education in IWRM amongst CBIs in south west Nigeria.

It is pertinent to state that membership of NWRCBNet is being drawn from capacity building institutions based in south west Nigeria and engaged directly in education and/or training and/or research in various fields relevant to water resources development and management. Membership shall be on an equal and individual basis and it shall be free of charge. Members require committing themselves to the objectives of the Network and are willing to participate in the activities of the Network presented in Figure 2, through joint research, education, training, and sharing of expertise, information, materials and facilities among members.

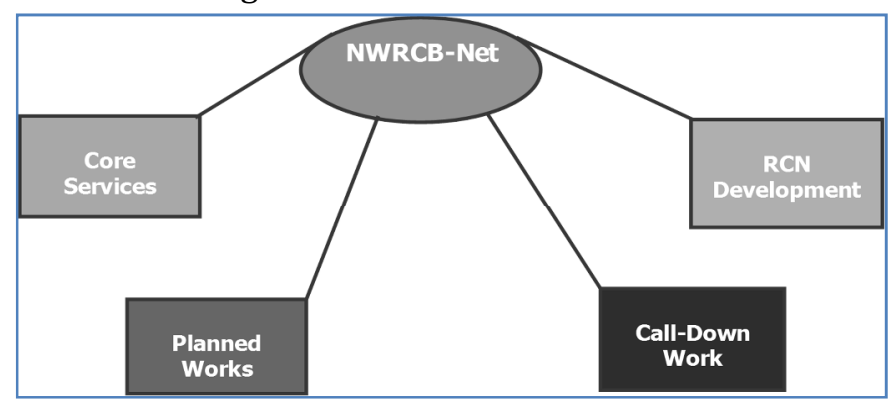

Figure 2: Activities of NWRCBNet Nigeria[9]

The core services that will be provided by the network are as shown in figure 3. The need for all scientist and professionals in the water sector to come together to support and participate in this development initiative cannot be over emphasized. Efforts are ongoing to access development funds from donors agencies like UNESCO, World Bank etc. to fast track the initiative of entrenching IWRM principles in the development and management of water resources in south west Nigeria. In order to disseminate the activities of the network and also create awareness, an internet group page has been established for the network in the region, the site also has relevant documents and books repository for the water disciplines, efforts are ongoing to upload links to recent research works in the water related disciplines on the water resources of the region. Interested water sector professionals in CBIs and WSOs as well as the water industry are encouraged to assess the web site using the addresses provided below:
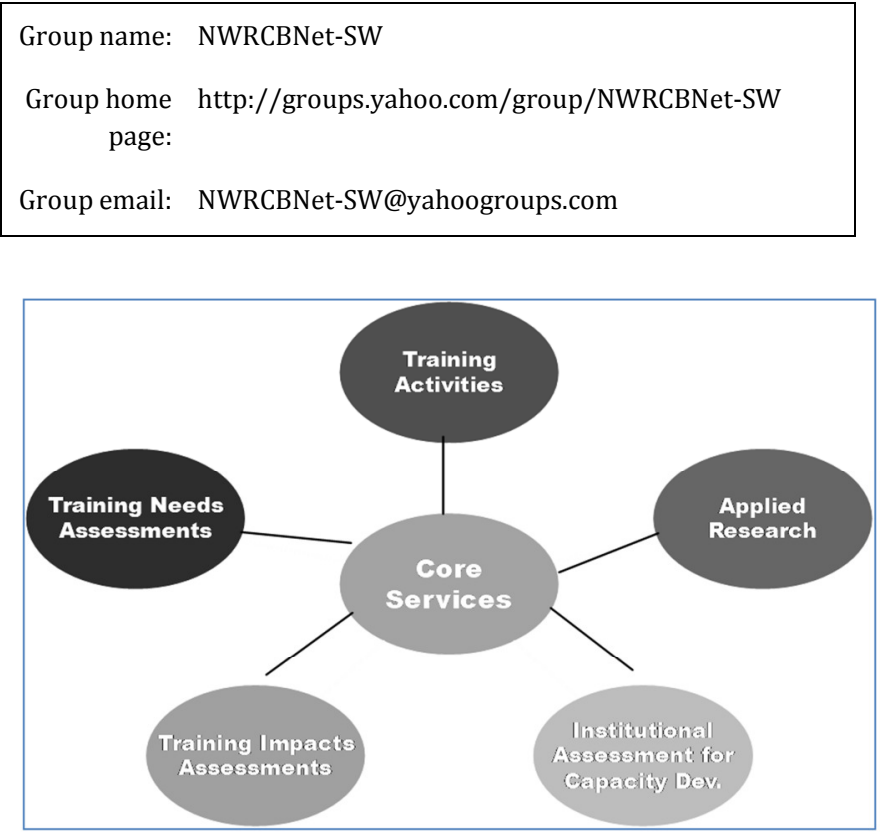

Figure 3: The core services to be provided by NWRCBNet-SW

\section{CONCLUSIONS}

The need to adopt IWRM principles in the development and management of the water resources of south west Nigeria cannot be over emphasized; everyone in the water sector must realize that the only way to harness the expertise in the sector is through collaboration and partnership between CBIs and WSOs. The new NWRCBNet initiative needs to be supported and encouraged by governments in the region. Water sector professionals domiciled in CBIs in the region have a leading role to play so that water resources development and management could be enhanced in the south west region of Nigeria.

\section{REFERENCES}

[1] Gumbo, B. and Van der Zaag, P. Principles of Integrated Water Resources Management. Global Water Partnership in Southern Africa, Southern Africa Youth Forum, 24th $-25^{\text {th }}$ September, 2001, Harare, Zimbabwe, p 138 - 146.2001.

[2] Wood, S., Sebastian, K., Scherr, S. J. Pilot analysis of global ecosystems: Agroecosystems. World Resources Institute, Washington D.C., USA. 2000

[3] Rees, J. A. Risk and Integrated Water Management. TEC Background Papers, No. 6, Global Water Partnership, Stockholm. 2002

[4] Sobowale A. River Basin Development: IWRM is the way forward. Kada Agricultural Engineer, 1(1): 34.2006

[5] United Nations, 2003. World Water Development Report. UNESCO 
[6] Truffer, B., Cebon, P., Dürrenberger, G., Jaeger, C., Rudel, R., and Rothen S. Innovative social responses in the face of global climate change. In: Views from the Alps. Regional Perspectives on Climate Change, edited by Cebon, P., Dahinden, U., Davies, H., Imboden, D., Jaeger, C. Boston, MIT Press. p.351434.1998.

[7] Asian Development Bank, Water For All. The Water Policy of Asian Development Bank. 2000.
[8] Perreira, L. S., Cordery, I. and Lacovides, I. Coping with water scarcity. IHP-VI Technical Documents in Hydrology, No. 58. UNESCO, Paris.2002.

[9] Bashir, D. Resource Centre Network Approach to Capacity Development in IWRM. Proceedings of the $2^{\text {nd }}$ National Water and Sanitation Conference, $20^{\text {th }}$ 24thMay, 2010, Kaduna, Nigeria, p. 234. 2010. 